\title{
The effect of duration of exposure to short days on the gonadal response to long days in male starlings (Sturnus vulgaris)
}

\author{
M. S. Boulakoud* and A. R. Goldsmith ${ }^{\dagger}$ \\ School of Biological Sciences, University of Bristol, Bristol BS8 IUG, UK
}

\begin{abstract}
Photorefractory male starlings (Sturnus vulgaris) were transferred from a photoperiodic schedule of $18 \mathrm{~h}$ light: $6 \mathrm{~h}$ dark to $8 \mathrm{~h}$ light:16 h dark for 2, 4, 6 or 10 weeks, and then photostimulated by exposure to $18 \mathrm{~h}$ light: $6 \mathrm{~h}$ dark. Testicular dimensions were measured at regular intervals by laparotomy. There was no change in testicular volume in birds photostimulated after 2 weeks under a photoperiod of $8 \mathrm{~h}$ light: $16 \mathrm{~h}$ dark, but a cycle of testicular growth followed by regression occurred in the other groups. Testicular volume was increased significantly by 20 days under $18 \mathrm{~h}$ light: $6 \mathrm{~h}$ dark in all three groups; regression began after 45,65 and 75 days in birds pre-exposed to $8 \mathrm{~h}$ light: $16 \mathrm{~h}$ dark for 4 , 6 and 10 weeks, respectively. These results are discussed in relation to other evidence for the progressive development of photosensitivity.
\end{abstract}

\section{Introduction}

The annual reproductive cycle in European starlings (Sturnus vulgaris) is generated by alternations between states of photosensitivity (induced and maintained by short days) and photorefractoriness (induced and maintained by long days). Only when they are photosensitive will birds become sexually mature in response to an increase in daylength. After prolonged exposure to long or increasing daylengths, the development of photorefractoriness terminates breeding and results in gonadal regression. Starlings become photosensitive again only after experiencing short or decreasing daylengths for a period of several weeks (Nicholls et al., 1988).

In photoperiodically controlled experiments, evidence has been found for both threshold and modulated responses to photoperiod in the change from photosensitivity to photorefractoriness, and vice versa. Although any photoperiod will facilitate gonadal growth in photosensitive starlings, the daylength must be $12 \mathrm{~h}$ or longer for the development of refractoriness. The rate at which refractoriness occurs (judged by the timing of gonadal regression) is proportional to daylength within the range $12 \mathrm{~h}$ light: $12 \mathrm{~h}$ dark to $18 \mathrm{~h}$ light: $6 \mathrm{~h}$ dark (Dawson and Goldsmith, 1983; Falk and Gwinner, 1983). Once in the photorefractory condition, a reduction in daylength to $12 \mathrm{~h}$ or shorter is required for the reacquisition of photosensitivity; the rate at which this occurs is then inversely proportional to daylength within the range $12 \mathrm{~h}$ light:12 h dark to $8 \mathrm{~h}$ light:16 h dark (Dawson, 1991; Boulakoud and Goldsmith, 1994).

A progressive restoration in endocrine and neuroendocrine function has been described in starlings during the first 6 weeks

*Present address: Institute of Biological Sciences, University of Annaba, BP 12, Algeria.

${ }^{+}$Correspondence.

Received 4 January 1995. after transferring photorefractory birds from $18 \mathrm{~h}$ light: $6 \mathrm{~h}$ dark to $8 \mathrm{~h}$ light:16 h dark (Dawson et al., 1986; Goldsmith et al., 1989). Changes include increases in immunocytochemical staining and hypothalamic content of GnRH, and in pituitary gonadotrophin content. The aim of the present study was to examine the time course of the restoration of gonadal responsiveness (to photostimulation), during recovery of photosensitivity under a photoperiod of $8 \mathrm{~h}$ light: $16 \mathrm{~h}$ dark.

\section{Materials and Methods}

Male starlings (Sturnus vulgaris), which had been captured locally, were kept in light-controlled rooms in metal cages measuring $0.6 \mathrm{~m} \times 0.5 \mathrm{~m} \times 0.4 \mathrm{~m}$, with five birds per cage. They had been under a photoperiodic regimen of $18 \mathrm{~h}$ light: $6 \mathrm{~h}$ dark for 5 months before the start of this experiment, and were therefore in the photorefractory condition. The starlings were divided into four groups, with five birds in each group. Different groups were exposed to short daily photoperiods of $8 \mathrm{~h}$ light:16 h dark for $2,4,6$ or 10 weeks, and then all were returned to long day photoperiods of $18 \mathrm{~h}$ light: $6 \mathrm{~h}$ dark.

Gonadal development was assessed by laparotomy at intervals of approximately 10 days. The birds were laparotomized under general anaesthesia, after i.m. injection of $70 \mu \mathrm{l}$ Sagatal (Wyvern Vet. Co., Chepstow) containing $4.2 \mathrm{mg}$ sodium pentobarbitone. The gonads were examined through a small incision in the body wall between the last two ribs, and the dimensions of the left testis measured to the nearest $0.5 \mathrm{~mm}$. Testicular volume was calculated as ${ }_{-4}^{4} \pi a^{2} b$, where $a$ is half the width of the testis at its widest point and $b$ is half the length.

Testicular volume data were analysed, after logarithmic transformation, by analysis of variance. Independent or repeated measures models were used as appropriate. Means were compared using the Fisher protected least significant difference test. 


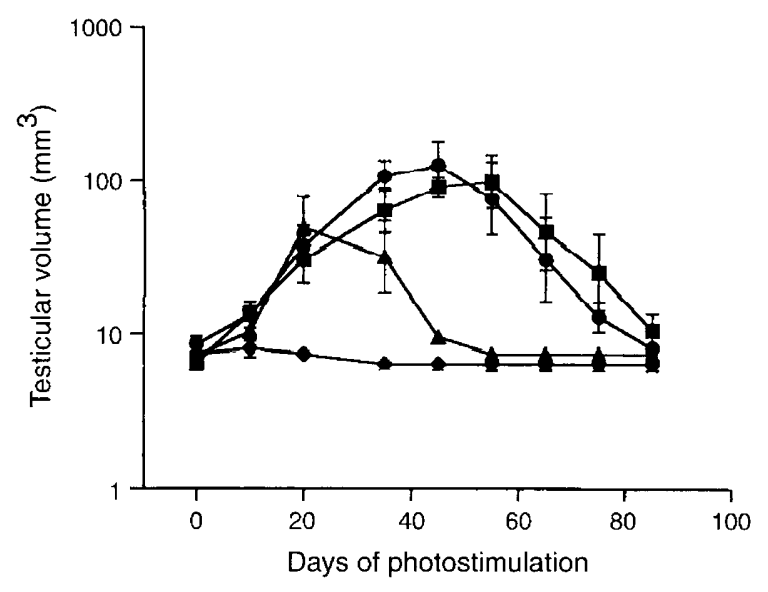

Fig. 1. Testicular volume in male starlings photostimulated by exposure to $18 \mathrm{~h}$ light: $6 \mathrm{~h}$ dark after pre-exposure to $8 \mathrm{~h}$ light: $16 \mathrm{~h}$ dark for $2(\bullet), 4(\bullet), 6(\bullet)$ or $10(\bullet)$ weeks. Values are geometric means $\pm \operatorname{SEM}(n=5)$.

\section{Results}

All birds had fully regressed testes when laparotomized for the first time at the end of their short day photoperiod and immediately before exposure to a photoperiod of long days (Fig. 1). There was no change in testicular volume in the birds that had received 2 weeks of short days $(\mathrm{F}(8,32)=2.30$, $P>0.05$ ). The birds that had received 4,6 and 10 weeks of short days all showed a significant testicular response to long days $(\mathrm{F}(8,32)=8.87 ; 11.50 ; 7.17, P<0.001$ in each case $)$. There was a significant increase in testicular volume by day 20 $(P<0.05)$ in all three groups. After this, the testes of the group exposed for 4 weeks began to regress, while gonadal growth continued in the groups exposed for 6 and 10 weeks for another $25-35$ days. The first significant $(P<0.05)$ reduction in testicular volume occurred between days 20 and 45,45 and 65 and 55 and 75 in the groups exposed for 4,6 and 10 weeks, respectively. Single factor analyses showed that testicular volume did not differ significantly between the groups exposed for 6 and 10 weeks at any stage of the experiment, but was larger $(P<0.05)$ in both than in the group exposed to 4 weeks on days 45,55 and 65 .

\section{Discussion}

Previously photorefractory male starlings that had been exposed to a photoperiod of $8 \mathrm{~h}$ light:16 h dark for only 2 weeks showed no testicular growth in response to photostimulation (exposure to $18 \mathrm{~h}$ light: $6 \mathrm{~h}$ dark). Photostimulation did promote a testicular cycle (growth followed by regression) in birds that had experienced 4,6 or 10 weeks under a photoperiod of $8 \mathrm{~h}$ light: $16 \mathrm{~h}$ dark, indicating that these birds had become photosensitive. Testicular growth rates, as inferred from laparotomy data after 10 and 20 days of exposure to $18 \mathrm{~h}$ light:6 h dark, did not differ among birds in these three groups. It is therefore possible that exposure for only 4 weeks to a photoperiod of $8 \mathrm{~h}$ light: $16 \mathrm{~h}$ dark is sufficient to restore maximal initial responsivity to long days in starlings. However, the timing of photorefractoriness, as evidenced by testicular regression, occurred much sooner in the birds exposed for 4 weeks rather than for 6 or 10 weeks to a photoperiod of $8 \mathrm{~h}$ light:16 $\mathrm{h}$ dark. This finding suggests a progressive development, during the first 6 weeks of exposure to $8 \mathrm{~h}$ light: $16 \mathrm{~h}$ dark, of the capacity to show the maximal duration gonadal response to photostimulation. The cycle duration was slightly shorter in birds pretreated for 6 weeks with $8 \mathrm{~h}$ light: $16 \mathrm{~h}$ dark than in those pretreated for 10 weeks, but at no time did testicular volume differ significantly between these two groups. Exposure for 6 weeks to a photoperiod of $8 \mathrm{~h}$ light:16 $\mathrm{h}$ dark therefore seemed sufficient for full restoration of photosensitivity in male starlings.

In several other birds, gonadal responsiveness to photostimulation has been shown to increase with duration of prior exposure to short days (Vaugien, 1955; Farner and Follett, 1966; Steel et al., 1975; Turek, 1975; Nicholis and Storey, 1977; Gwinner et al., 1988; Wilson, 1992; Wingfield, 1993; Silverin, 1994). Gonadal responsiveness has been variously assessed in terms of initial growth rate, amplitude of the response or cycle duration, and many of the studies reported, as demonstrated here in starlings, a minimal threshold duration of short days before any gonadal response is discernible.

The shortest period of exposure to a photoperiod of $8 \mathrm{~h}$ light: $16 \mathrm{~h}$ dark that restored gonadal responsiveness to long days in the present study was 4 weeks. This is in good agreement with the timing of the restoration of neuroendocrine and endocrine capacity, which occurs in male starlings during the acquisition of photosensitivity (Dawson et al., 1986; Goldsmith et al,, 1989). After exposure for 4 weeks to $8 \mathrm{~h}$ light: $16 \mathrm{~h}$ dark, there is a significant increase in hypothalamic content of $\mathrm{GnRH}$ and in intensity of immunostaining for $\mathrm{GnRH}$ in the neuronal cell bodies and axons. At this time, there are also significant increases in pituitary LH content, testicular mass and testicular testosterone content. LHRH content increases further between 4 and 6 weeks under a photoperiod of $8 \mathrm{~h}$ light: $16 \mathrm{~h}$ dark.

Another diagnostic feature of photosensitivity in starlings is the 'castration response'. Castrating photosensitive birds results in a rapid and sustained increase in circulating gonadotrophin concentrations, even under short days, whereas photorefractory birds show no such response (Goldsmith and Nicholls, 1984a). The timing of the spontaneous increase in plasma LH in castrated photorefractory male starlings transferred from $18 \mathrm{~h}$ light: $6 \mathrm{~h}$ dark to $8 \mathrm{~h}$ light:16 $\mathrm{h}$ dark is about 4-6 weeks (Goldsmith and Nicholls, 1984b; Williams et al., 1987; Boulakoud et al., 1991; Dawson, 1991; Boulakoud and Goldsmith, 1994); again in close agreement with the timing of the other physiological manifestations of photosensitivity. The increase in LH takes longer to begin, and concentrations rise more slowly, in castrated refractory starlings exposed to $11 \mathrm{~h}$ light:13 h dark or $12 \mathrm{~h}$ light: $12 \mathrm{~h}$ dark, indicative of a more gradual development of photosensitivity under these regimens than under $8 \mathrm{~h}$ light:16 h dark (Dawson, 199I; Boulakoud and Goldsmith, 1994).

Close coupling of the timing of the castration-induced LH increase with the development of photosensitivity is emphasized by observations of nestling starlings reared under $8 \mathrm{~h}$ light:16 h dark. Both the increase in GnRH content in intact birds and the castration response occur about 3 weeks later 
than when fully grown photorefractory starlings are exposed to $8 \mathrm{~h}$ light:16 h dark (Dawson and Goldsmith, 1989). McNaughton et al. (1992) demonstrated that starlings cannot respond to short days for the first 3 weeks after hatching.

In many birds, the castration-induced rise in LH occurs spontaneously under short days, but in photosensitive tree sparrows and Harris' sparrows, LH concentrations are low unless the birds are photostimulated by exposure to long days (Wilson, 1990, 1992). In Harris' sparrows, gonadal responsiveness in intact birds and gonadotrophin hypersecretion in castrates (in response to photostimulation) both increase progressively during acquisition of photosensitivity, but the relative timing is not as closely linked as it is in starlings (Wilson, 1992).

\section{References}

Boulakoud MS and Goldsmith AR (1994) Acquisition of photosensitivity in castrated male starlings (Sturnus vulgaris) under short daily photoperiods Journal of Reproduction and Fertility 100 77-79

Boulakoud MS, Ivings WE and Goldsmith AR (1991) Thyroxine treatment prevents the development of photosensitivity in European starlings (Sturnus vulgaris). Journal of Comparative Physiology B 161 516-520

Dawson A (1991) Effect of daylength on the rate of recovery of photosensitivity in male starlings (Sturnus vulgaris) Journal of Reproduction and Fertility $93521-524$

Dawson A and Goldsmith AR (1983) Plasma prolactin and gonadotrophins during gonadal development and the onset of photorefractoriness in male and female starlings (Sturnus vulgaris) on artificial photoperiods Journal of Endocrinology $97253-260$

Dawson A and Goldsmith AR (1989) Sexual maturation in starlings raised on long or short days: changes in hypothalamic gonadotrophin-releasing hormone and plasma $\mathrm{LH}$ concentrations Journal of Endocrinology $\mathbf{1 2 3}$ 189-196

Dawson A, Goldsmith AR, Nicholls TJ and Follett BK (1986) Endocrine changes associated with the termination of photorefractoriness by short daylengths and thyroidectomy in starlings (Stumus vulgaris) Journal of Endocrinology 110 73-79

Falk H and Gwinner E (1983) Photoperiodic control of testicular regression in the European starling Naturwissenschaften 70 257-258

Farner DS and Follett BK (1966) Light and other environmental factors affecting avian reproduction Journal of Animal Science Supplement 25 90-118
Goldsmith AR and Nicholls TJ (1984a) Prolactin is associated with the development of photorefractoriness in intact, castrated, and testosteroneimplanted starlings General and Comparative Endocrinology 54 247-255

Goldsmith AR and Nicholls TJ (1984b) Recovery of photosensitivity in photorefractory starlings is not prevented by testosterone treatment General and Comparative Endocrinology $56 \quad 210-217$

Goldsmith AR, Ivings WE, Pearce-Kelly AS, Parry DM, Plowman G, Nicholls T] and Follett BK (1989) Photoperiodic control of the development of the LHRH neurosecretory system of European starlings (Sturnus vulgaris) during puberty and the onset of photorefractoriness Journal of Endocrinology $\mathbf{1 2 2}$ $255-268$

Gwinner E, Dittami JP and Beldhuis HJA (1988) The seasonal development of photoperiodic responsiveness in an equatorial migrant, the garden warbler Sylvia borin Journal of Comparative Physiology A 162 389-396

McNaughton FJ, Dawson A and Goldsmith AR (1992) Puberty in birds: the reproductive system of starlings does not respond to short days until birds are fully grown Journal of Endocrinology 132 411-417

Nicholls TJ and Storey CR (1977) The effect of duration of the daily photoperiod on recovery of photosensitivity in photorefractory canaries (Serinus canarius) General and Comparative Endocrinology 31 72-74

Nicholls TJ, Goldsmith AR and Dawson A (1988) Photorefractoriness in birds and comparison with mammals Physiological Reviews 68 133-176

Silverin B (1994) Photoperiodism in male great tits (Parus major) Ethology, Ecology and Evolution 6 131-157

Steel E, Follett BK and Hinde RA (1975) The role of short days in the termination of photorefractoriness in female canaries (Serinus canarius) Journal of Endocrinology 64 451-464

Turek FW (1975) The termination of the avian photorefractory period and the subsequent gonadal response General and Comparative Endocrinology 26 562-564

Vaugien L (1955) Sur les reactions testiculaires du jeune moineau domestique illuminé à diverses epoques de la mauvais saison Bulletin Biologique de la France et de la Belgique 89 218-244

Williams TD, Dawson A, Nicholls TJ and Goldsmith AR (1987) Short days induce premature reproductive maturation in juvenile starlings, Sturnus vulgaris Journal of Reproduction and Fertility 80 327-333

Wilson FE (1990) On the recovery of photosensitivity in two passerine species, American tree sparrows (Spizella arborea) and Harris' sparrows (Zonotrichia querula) General and Comparative Endocrinology $79283-290$

Wilson FE (1992) Photorefractory Harris' sparrows (Zonotrichia querula) exposed to a winter-like daylength gradually regain photosensitivity after a lag General and Comparative Endocrinology 87 402-409

Wingfield JC (1993) Control of testicular cycles in the song sparrow, Melospiza melodia melodia: interaction of photoperiod and an endogenous program? General and Comparative Endocrinology 92 388-401 